\title{
Development of Wine Industry in Spain: Three Pioneer Regions in Commercial Wine Production
}

\author{
SAITO Yuka* and TAKENAKA Katsuyuki** \\ *Graduate Student, Nagoya University, Nagoya, Aichi 464-8601, Japan \\ **Faculty of Foreign Studies, Aichi Prefectural University, Nagakute, Aichi 480-1198, Japan
}

\begin{abstract}
Wine industry in Spain, consolidated as a sector with ancestral traditions, has experienced in the last decades a new dynamism that raises it to a highly competitive position in the international market. However, against what could be expected from the current situation, commercialization of wine production arrived in Spain in relatively recent periods and was limited, at least in the initial stages, to some few areas of the country. In this article, three pioneer regions, Jerez, Penedès and Rioja, are selected to analyze the transition to commercial wine production in a comparative perspective. Special attention is paid to the leading entrepreneurs of each region that played an important role to develop the potential of the sector with modern vinification methods. Careful survey on these three regions reveals that what distinguishes each region from the others is not only the geographical or economic origin of the leading entrepreneurs, but the way they responded to the physical and locational conditions proper to each region. Distinctive behaviors of the leaders also conditioned to a great extent the relationship to be established with the other operators involved in the wine industry. Finally, some spatial implications of this relationship are pointed out through considerations on the physical and functional differences found inside of the region.
\end{abstract}

Key words: wine industry, entrepreneur, physical conditions, geographical location, Spain

\section{Introduction}

In the economic development of Spain, characterized by its late industrialization with massive entrance of foreign capital, food processing industry stands out as one of the sectors that, led by dynamic endogenous capital, have made a steady progress in the last few centuries. In particular, wine industry in Spain is a sector of special relevance for its cultural and historical singularity and also its competitiveness that has been raised in the last decades.

The origin of wine-making in Spain goes back to the second millennium B.C., and since the Roman Empire gained dominion over the Iberian Peninsula in the second century B.C., wine production was expanded progressively all over the country. However, the transition from wine-making for local consumption to commercialized production did not take place until relatively recent periods. By the end of the nineteenth century, commercial wine production on a large scale had not emerged yet in
Spain except in Jerez, where a prosperous wine industry had developed from the sixteenth century, driven by the export of its famous sherry. The experience of Jerez was followed by other regions, such as Penedès or Rioja, which went through a rapid modernization process in vinification methods to become soon the most prestigious wine-producing regions in whole Spain.

What is common among these three pioneer regions in commercial wine production is the important role played by the entrepreneurs in the creation and development of new products supported by modern vinification methods. These innovative changes permitted them to elaborate high quality wine with distinguishing characters and then present their renewed products in domestic and international markets.

However, behind the success of these wineproducing regions, there was something more than simple entrepreneurship. Physical and locational conditions should also be taken into account in determining the potential of each region. Indeed, as wine-making consists essen- 
tially in the fermentation of grapes, physical conditions of the area where the vines are grown, such as climate or soil, have notable effects on the quality and characteristics of the final product. Furthermore, when a region enters into commercial-oriented production, it is also indispensable to have access to an exterior market. Then, proximity to the market or availability of means of transportation at low costs acquire a crucial importance as factors of sales potential (Saito 2004).

For a successful transition to commercialoriented wine production, the entrepreneurs had to take advantage of their surrounding conditions, that is, physical environment, accessibility to the market or availability of means of transportation. However, these conditions differ considerably from region to region, as does the way the entrepreneurs exploited them. These two aspects, when combined, lead to impressive diversity in the development of commercial wine production, a diversity expressed in both quantitative and qualitative aspects of the products.

In the following pages, the development of three pioneer regions in commercial wine production, Jerez, Penedès and Rioja, will be analyzed in some detail (Figure 1). Special attention will be paid to the role that the leading entrepreneurs played, as well as the relation- ship established between that group of entrepreneurs and the other operators involved in the wine industry. And all these questions will be treated in close relation to the surrounding conditions mentioned above.

As for the geographical delimitation of each region, we have adopted the boundary established by the current Denomination of Origin (DO). ${ }^{1}$ In the three regions, the first DO regulations came into force between the 1930s and the 1960s for the purpose of guaranteeing the registered producers the exclusive use of the $\mathrm{DO}$, and also controlling the whole production process and the quality of final products (Table $1)^{2}$

In the section corresponding to Penedès, the production of cava, a kind of sparkling wine of Catalan origin, will be also considered, even though it is under the control of an independent DO. The registration of operators in the DO Cava is based on a specific production method (champagne method), contrary to the other DOs which are geographically delimitated. Although the DO Cava operates for all the cava producers of Spain located in seven Autonomous Communities, around $90 \%$ of the total production of cava is realized by wine-growers located in the DO Penedès, which in most cases combine the elaboration of cava with that of still wine. Such degree of concentration as well

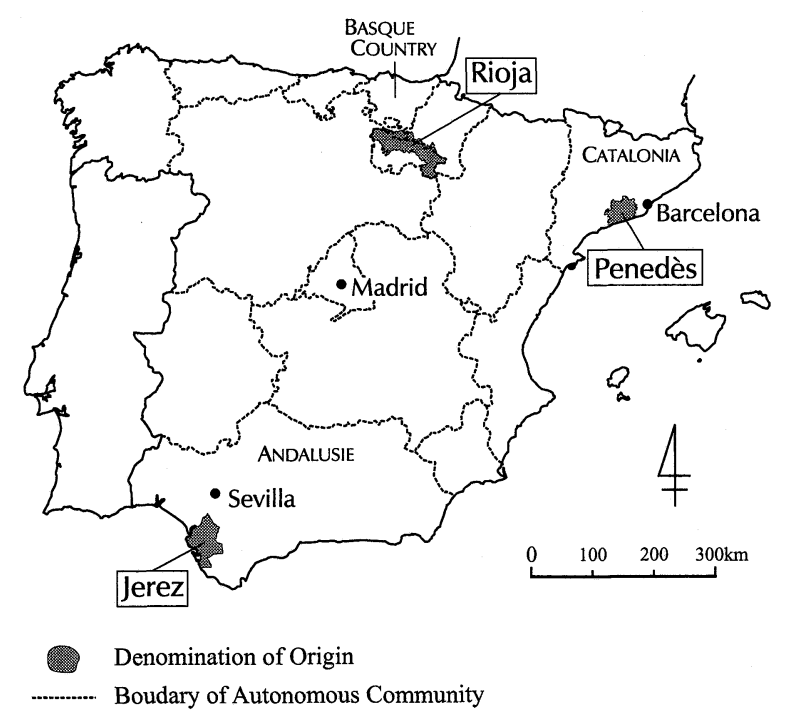

Figure 1. Location of the three Denominations of Origin. 
Table 1. Summary of the three Denominations of Origin

\begin{tabular}{|c|c|c|c|}
\hline Denomination of Origin & Jerez & Penedès & Rioja \\
\hline Initial regulations & 1935 & 1960 & 1947 \\
\hline Registered vineyards & 10,359 ha & 27,692 ha & 59,605 ha \\
\hline Geographical situation & Atlantic & Mediterranean & Interior \\
\hline Average annual temperature & $17.5^{\circ} \mathrm{C}$ & $14.4^{\circ} \mathrm{C}$ & $12.8-13.9^{\circ} \mathrm{C}$ \\
\hline Average annual precipitation & $600 \mathrm{~mm}$ & $514 \mathrm{~mm}$ & $370-450 \mathrm{~mm}$ \\
\hline Type of soil & $\begin{array}{l}\text { limestone (albariza), } \\
\text { gravel, clay }\end{array}$ & gravel, limestone & $\begin{array}{l}\text { Alavesa: chalky clay } \\
\text { Alta: ferrous clay } \\
\text { Baja: alluvial }\end{array}$ \\
\hline Annual sunlight & 3,000 hours & 2,500 hours & 2,800 hours \\
\hline $\begin{array}{l}\text { Authorized varieties: } \\
\text { white grapes } \\
\text { (*with priority) }\end{array}$ & $\begin{array}{l}\text { palomino fino } \\
\text { pedro ximénez } \\
\text { moscatel }\end{array}$ & $\begin{array}{l}\text { macabeu } \\
\text { parellada } \\
\text { xarel·lo } \\
\text { subirat parent }\end{array}$ & $\begin{array}{l}\text { garnacha blanca } \\
\text { malvasía blanca } \\
\text { viura* }\end{array}$ \\
\hline $\begin{array}{l}\text { Authorized varieties: } \\
\text { black grapes } \\
\text { (*with priority) }\end{array}$ & none & $\begin{array}{l}\text { cabernet sauvignon } \\
\text { garnacha } \\
\text { mazuelo } \\
\text { monastrell } \\
\text { samsó } \\
\text { ull de llebre(tempranillo) }\end{array}$ & $\begin{array}{l}\text { garnacha } \\
\text { graciano } \\
\text { mazuelo } \\
\text { tempranillo* }\end{array}$ \\
\hline Principal products & sherry & cava*, white, red & red \\
\hline Registered vine-growers & 2,821 & 5,681 & 19,597 \\
\hline Registered wine producers & 104 & 274 & 1,602 \\
\hline Bottling producers & 64 & 189 & 491 \\
\hline Non-bottling producers & 40 & 85 & 1,111 \\
\hline Volume of qualified wine & $1,307,133 \mathrm{~h} l$ & $455,172 \mathrm{~h} l$ & $2,417,253 \mathrm{~h} l$ \\
\hline Sales & $703,658 \mathrm{~h} l$ & $385,988 \mathrm{hl}$ & $2,485,259 \mathrm{hl}$ \\
\hline National & $136,629 \mathrm{hl}$ & $256,218 \mathrm{~h} l$ & $1,807,269 \mathrm{hl}$ \\
\hline International & $567,029 \mathrm{~h} l$ & $129,770 \mathrm{~h} l$ & $677,990 \mathrm{~h} l$ \\
\hline $\begin{array}{l}\text { Traditional production } \\
\text { methods }\end{array}$ & solera system & $\begin{array}{l}\text { elaboration of cava*, } \\
\text { early introduction of } \\
\text { stainless steel tank and } \\
\text { thermoregulation system }\end{array}$ & $\begin{array}{l}\text { Bordelais method, } \\
\text { aging in oak casks }\end{array}$ \\
\hline Predominant capital & foreign capital & $\begin{array}{l}\text { local capital } \\
\text { (family company) }\end{array}$ & $\begin{array}{l}\text { local capital, } \\
\text { national/foreign capital }\end{array}$ \\
\hline
\end{tabular}

* The production of cava is treated as an integral part of the wine-making activities developed inside the DO Penedès, although from a strictly institutional viewpoint it is under the control of the DO Cava that operates for all the cava producers of Spain.

Source: Grupo Gourmets (2002), Ministerio de Agricultura, Pesca y Alimentación (2002) and authors' field survey.

as the special importance of the production of cava for the local economy justify its inclusion in the analysis as an integral part of the winemaking activities developed inside the DO Penedès.

The information on which this study is based was obtained in the field survey we conducted in three occasions from 2002 to 2003 , and is complemented by extensive statistical and documental information. The Regulatory Councils of the three DO facilitated our work by providing detailed information on the current regulations and the registered wine producers. Also several producers of each region, belonging to different types of operators, were selected for additional survey. ${ }^{3}$ 

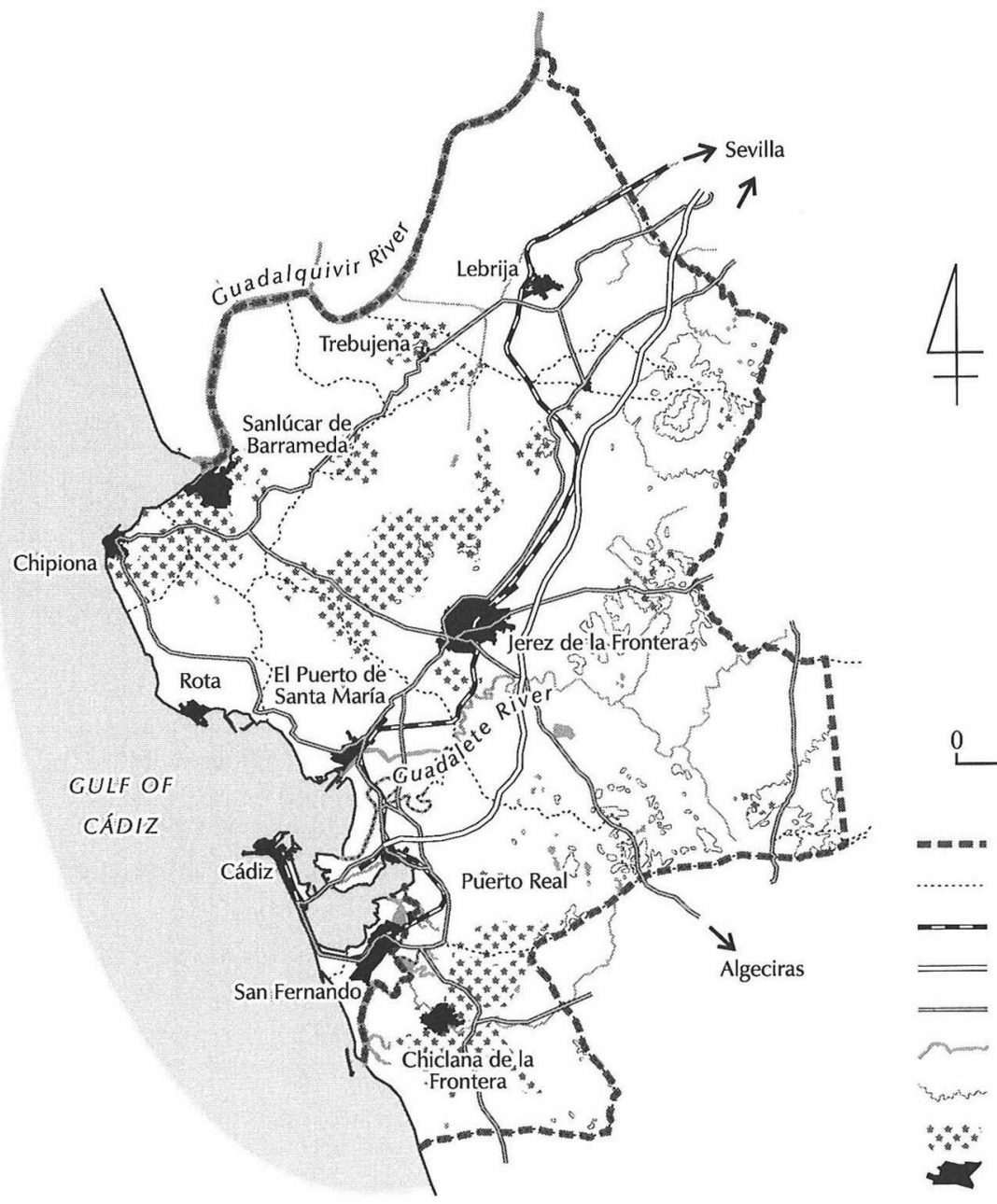

Figure 2. General situation of the Denomination of Origin of Jerez.

\section{Jerez}

Jerez, well-known by its distinguished and prestigious sherry, is the first Spanish region in experiencing the arrival of commercial-oriented wine production. As early as the sixteenth century, the reputation of sherry had already reached principal foreign markets (Ramos Santana 1997: 85-86).

After the Hundred Years' War (1337-1453), in which England lost its wine-producing region of Gascony to France, Spain and Portugal began to acquire importance in the English market as new suppliers of sweet wine, for which the demand was growing among the English people. Wine export from the Iberian Peninsula to England showed a gradual increase from the sixteenth century, and it was in Jerez where this trade best profited (Unwin 1996: 221).

Among the stimulating factors for the wine trade in Jerez, geographical location was of fundamental importance (Figure 2). In fact, the ports on the nearby coast worked as an Atlantic gate for the Jerez region. The availability of port facilities guaranteed access to foreign markets and encouraged the English merchants to settle in this region. Another factor of importance was the specialization of Jerez in fortified wine. When there was no sophisticated preservation method, fortified wine had the advantage of permitting the long sea voyage to Eng- 
land without deterioration in quality.

As sherry became popular in the English market, a large number of English merchants came to settle in Jerez seeking to establish more fluid channels of supply to England. They established a small merchant colony in Sanlúcar de Barrameda, at the mouth of Guadalquivir river, and exported the wine produced around the town of Jerez de la Frontera from the port of Sanlúcar or of nearby Cádiz (Unwin 1996: 222).

Sherry was also exported to Latin America from the ports of Sevilla and Cádiz, which had monopoly for the trade with the American colonies until it was opened to other ports of Spain in the last decades of the eighteenth century (Guerrero Cano 1998). At the end of the six- teenth century, Jerez represented $52 \%$ of all the wine shipped from Sevilla to the New World. Nevertheless, the most important client for Jerez was probably England, although it is difficult to know the exact amount of wine export at that period (Huetz de Lemps 1993: 83).

The second half of the eighteenth century to the middle of the next century was for Jerez the epoch of great expansion of the wine industry, pulled by the growing demand for sherry in the English market. An increasing number of foreign commercial capitalists were attracted to the region, and some of them, with their own bodegas established near the urban center, soon began to conduct the development of the whole sector. To mention some representative cases,

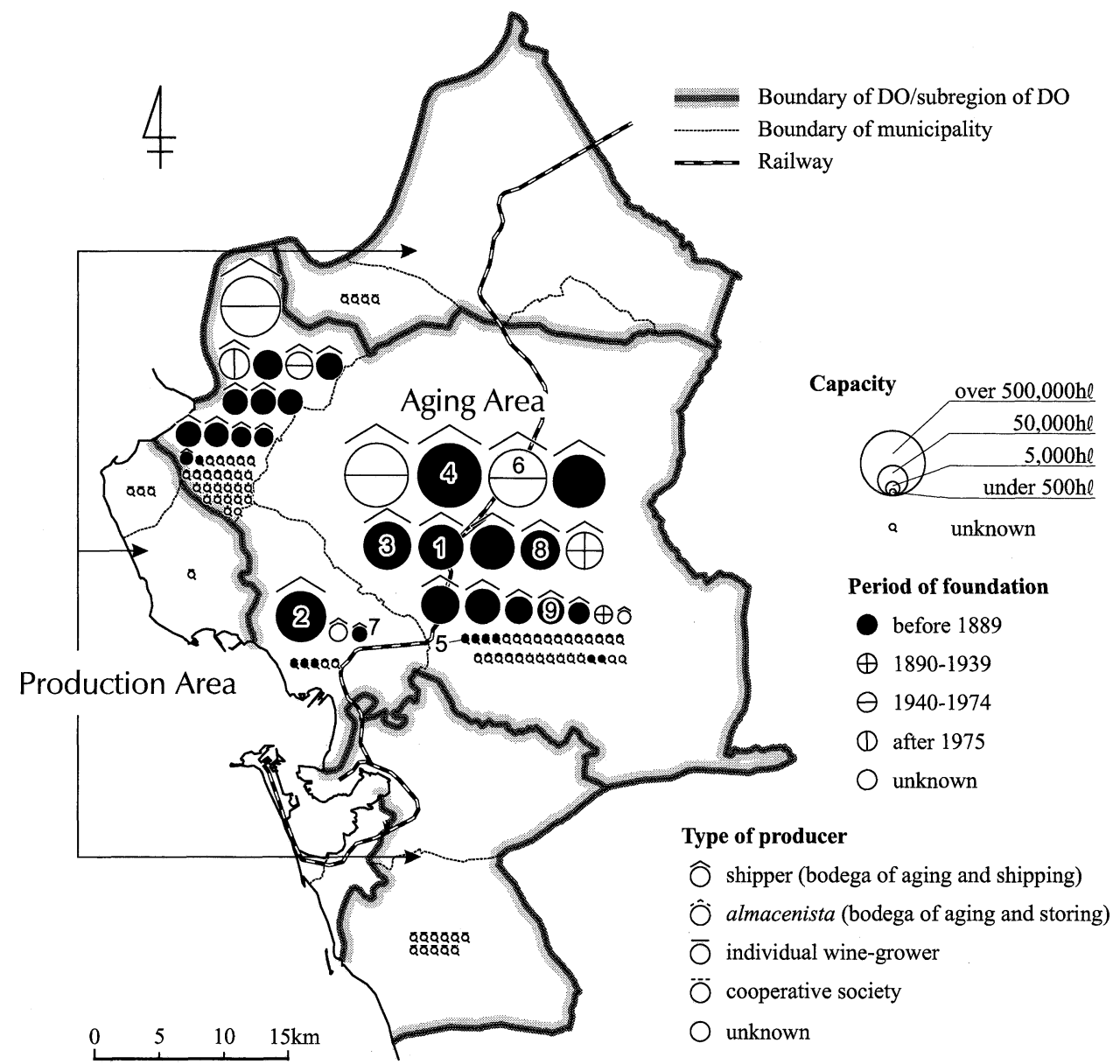

Figure 3. Registered wine producers in the Denomination of Origin of Jerez (2002).

Note: Shippers include also those cooperative societies that are engaged in aging and shipping as a fundamental part of their activities.

Source: Ediciones El País (2002), Consejo Regulador de la Denominación de Origen de Jerez (2002). 
the Irish Patrick Murphy, founder of Pedro Domecq (1), ${ }^{4}$ came to Jerez in 1730 , and associated with a French merchant, called Jean Haurie, to begin the trade of sherry (Figure 3). English consul at Cádiz, the Scottish James Duff founded Duff Gordon in 1767. Thomas Osborne from Devon established in 1772 the company Osborne (2) in El Puerto de Santa María, and the Irish William Garvey settled in Jerez de la Frontera in 1780 to found a company to which he put his own name (3) (Huetz de Lemps 1993: 84).

Along with foreign merchants, there was a remarkable participation of indianos, Spanish emigrants to Latin America who returned home with fortunes made abroad. From the 1820 s to the 1830s, an important amount of capital was invested by indianos who went back to Spain after the independence of Spanish colonies. Also some merchants from northern Spain participated in this surge of investment in Jerez (Maldonado Rosso 1999: 260-262).

For the reproduction and reinforcement of the image generated around the products of Jere $z$ in the international market, the singularity of Jerez in physical conditions, especially in edaphic aspects, had a special significance. The dominant type of soil in Jerez is a kind of limestone, called albariza. Rich in calcium carbonate, albariza soil can absorb a large quantity of water and maintain it underground in winter. In dry seasons, the surface of albariza gets solid enough to impede the evaporation, and the vine can be provided with sufficient water as it requires. Furthermore, the sunlight reflected by the white chalky soil of albariza encourages the grapes to mature and raises their sugar content (Bachelard et al. 2002: 186). The vineyards most enriched with albariza soil are found in the triangle area surrounded by three towns: Jerez de la Frontera, Sanlúcar de Barrameda and El Puerto de Santa María (Figure 2). Today, this area is called the "Sherry Triangle" or "Jerez Superior" and is regarded as privileged for the production of sherry.

Additional mention should be made of palomino, the most characteristic and prestigious grape variety of Jerez. At present, palomino is cultivated in approximately 95\% of the vineyards of the region, although it is unknown to what extent this was the case in past centuries.

In the second half of the nineteenth century, a change took place in the English market: Wine was no longer demanded just as dessert liquor, but rather as an aperitif or accompaniment to a meal. The demand for fresh wine grew gradually, and this change led the wine producers of Jerez to create a new type of wine, called fino (Simpson 1985: 170). In the production process of fino, the veil of yeast, flor, is formed over the surface of wine, which keeps it out of contact with the air limiting oxidation to the minimum. The resulting product, fresh and dry wine with characteristic aroma, was soon accepted with enthusiasm in the international market. In this way, Jerez came to be a typical example of a wine-producing regions adapting to the changing market to continue growing in detriment of other regions, such as Málaga, Port or Madeira which, clinging to their traditional way of production centered on sweet fortified wine, soon showed symptoms of stagnation.

While the export of fino was expanding, the elaboration method also experienced an important evolution. The prevalent method at the beginning of the nineteenth century, the socalled añada system, consisted of aging wine for many years in a single cask that corresponded to a certain year of harvest. Under this system, however, the quality of wine would differ considerably by vintage, against the demand of the English market that required a more stable and homogeneous product (Simpson 1997: 137138).

The solera was the system developed to overcome this limitation. This new aging system introduced the use of several casks by which wine of different years is mixed gradually, so that products of stable quality could be obtained every year. In addition, the solera has an important advantage over the añada system to produce fino, because through the mixture process, the nutrition required to generate flor is transmitted from new wine to old (Maldonado Rosso 1999: 165). That was why the solera became the dominant wine-making method in Jerez, and therefore the pulling force for the commerce of fino in the English market, which came to be even more prosperous than ever. 
However, the introduction of solera required a considerable investment because of the costs of installing great quantities of casks and building the cellars to store them. Therefore, those who could introduce it first were the exporters with fortunes made from the sherry trade, and most of them were or had their origin in foreign merchants settled in Jerez for many decades. These exporters gradually enforced their control over the wine industry in Jerez, investing in the establishment of great bodegas, frequently accompanied with a wide extension of vineyards (Montañés 2001: 193).

Today, the bodegas of Jerez are categorized by the Regulatory Council into three types: shippers (bodegas of aging and shipping), almacenistas (bodegas of aging and storing) and elaboration bodegas. The shippers, with their control over the solera, play an important role not only as exporters of wine, but also as producers. ${ }^{5}$ The almacenistas specialize in aging wine to provide it later to shippers. ${ }^{6}$

In Jerez, there is a considerable concentration of wine production to a relatively small number of shippers and almacenistas of large or medium dimensions (Figure 3). Especially, some shippers established in Jerez de la Frontera possess hundreds of hectares of vineyards located in "Jerez Superior," that is, in the area of albariza soil (e.g. Pedro Domecq 1,100 ha, González Byass $650 \mathrm{ha}$ ), and as commented above, most of them are in the hands of multinational companies that evolved from exporters of sherry. Particularly paradigmatic of this situation is the acquisition of Pedro Domecq by Allied Lyons in 1994, a multinational company that today also possesses some of the most well-known bodegas in Rioja.

Special mention should be made of the wine produced by the bodegas located in Sanlúcar de Barrameda, which are generally small and medium-sized bodegas of Spanish origin, in most cases family companies. The wine of Sanlúcar, called manzanilla, is slightly different from the fino produced in other parts of the Jerez region, as a result of the microclimatic conditions in which this coastal town is found: In Sanlúcar, cooler and more humid than in Jerez de la Frontera, more abundant flor is generated and maintained through the year (Jeffs 2000: 313).
These special conditions make manzanilla paler and less dry than fino, and then more popular in the Spanish national market.

By regulations of the Regulatory Council, shippers and almacenistas can be located exclusively in the municipalities of Jerez de la Frontera, El Puerto de Santa María and Sanlúcar de Barrameda, defined together as the "Aging Area," and only bodegas located in this area are entitled to use the DO of Jerez (Figure 3). Endowed with an extensive surface of albar$i z a$ soil, the "Aging Area" is considered to be under the most appropriate conditions to produce sherry, although the decision of restricting the area to the three municipalities is basically due to their historical status as the leading center of sherry production, reinforced by the presence of imposing soleras. ${ }^{7}$

On the other hand, the elaboration bodegas can be located in any place of the Jerez region, including six municipalities that constitute the "Production Area," besides the three already mentioned (Figure 3). This area is edaphically formed by sandy and clayey soils, which give less adequate conditions to grow grapes of high quality like palomino.

Elaboration bodegas consist of individual wine-growers (cosecheros) and cooperative societies. Traditionally these local producers, lacking capital to invest in solera, specialize in providing must $^{8}$ for large bodegas, which commercialize it with their own brand after several years of aging. And many of the vine-growers equipped insufficiently to realize vinification decided to associate in cooperative societies. Sometimes elaboration bodegas, whether individual or cooperative, also sell part of their products to the consumer market, mainly sweet wine made from moscatel grapes, but the fundamental activity of these bodegas continues to be the elaboration of must.

What differentiates Jerez clearly from the other two wine-producing regions is the relatively small number of wine producers: 104 in the year 2002, of which only 64 are bottling producers (shippers and almacenistas), while in Penedès the number of the latter ascends to 189 and in Rioja to 491 (Table 1). Certainly the difference is remarkable, even in relation to the volume of wine production in each region, and 
it is a testimony of the power exerted by large bodegas of Jerez, basically of foreign capital.

Considering the large amount of grapes and must sold among different types of operators, the concentration of wine production noted above cannot be translated quantitatively into concentration of vineyards, but from a qualitative viewpoint, the control of large-sized bodegas over vineyards is quite important. In fact, over $90 \%$ of the vineyards of "Jerez Superior," with adequate conditions to raise grapes of high quality, is situated in the three municipalities belonging to the "Aging Area." It is in this area where the dominion of large bodegas has been strengthened through purchase of the most attractive vineyards. On the contrary, where sandy and clayey soils are dominant, the vine, often combined with other crops, is normally cultivated by peasants associated in cooperatives and independent vine-growers.

Nowadays, many cooperative societies realize considerable investments in the modernization of equipment so as to get the best profit from their own lands and to gain force in the more and more competitive market. However, the most important restructuring process is taking place from above, that is, from the large bodegas that, with their historical fame engraved in old solera casks, try to integrate the whole production process, controlling or buying the best vineyards found in the region.

Recently, the tendency toward oligopoly has been more intensified through mergers and acquisitions realized by some big companies. Affiliating with various bodegas of the region, they have developed groups of considerable dimensions: González Byass (4) has affiliated with Wisdom \& Warter (5) and Croft Jerez (6), Pedro Domecq with Bodegas Terry (7) and Bodegas Harveys (8), Garvey with José de Soto (9), etc.

The activities of some big companies extend beyond the limit of the DO Jerez. Since the 1970 s, principal companies of Jerez have been penetrating progressively in other regions, especially in Rioja, establishing new wineries or purchasing existing installations. Osborne and González Byass, besides the already mentioned Pedro Domecq, are some successful cases in diversifying products through expansion to other regions.

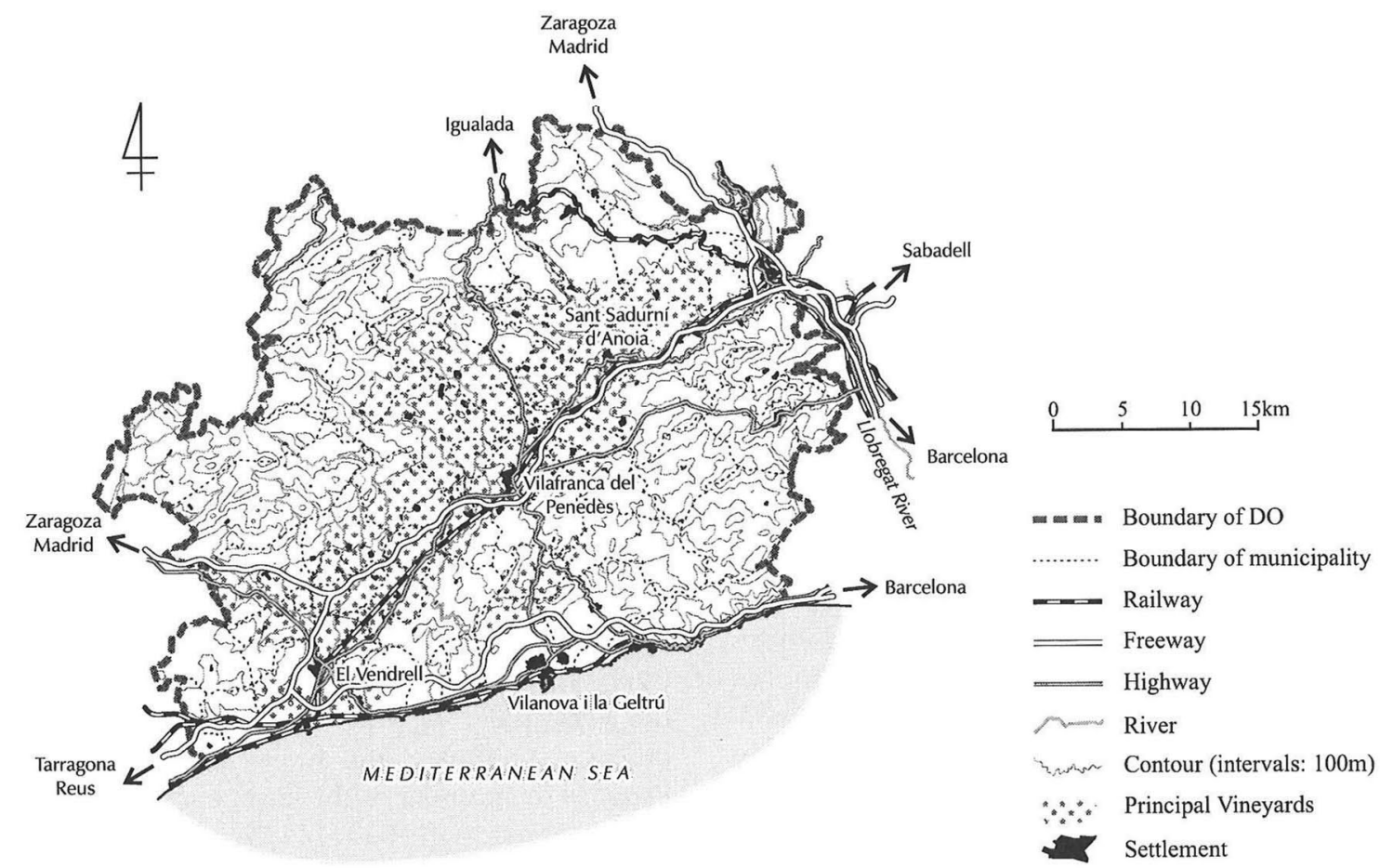

Figure 4. General situation of the Denomination of Origin of Penedès. 


\section{Penedès}

Among the wine-producing regions of Spain, Penedès is not normally considered to be outstanding in physical conditions. Although its vineyards, situated from the coast up to $800 \mathrm{~m}$ above sea level, have a climatic and edaphic diversity that permits to cultivate a great variety of grapes, they are not always appreciated and well exploited to produce wine of quality (Table 1, Figure 4). Contrary to Jerez that was driven by an extraordinary demand for sherry since early modern times, favorable international circumstances did not appear in Penedès until the eighteenth century.

However, as a typical Mediterranean plant, the vine had always been cultivated by peasants of the region for their own needs, or in response to the demand of the urban population. In fact, the Catalan littoral was one of the most densely populated areas in Spain, and its commercial and industrial centers led by Barcelona constituted a market of considerable importance for the surrounding wine-producing regions. Under these conditions, the wine production in Penedès was destined almost exclusively for local and regional consumption and the export was quite limited until the seventeenth century with the exception of malvasia, a sweet white wine produced in the coastal town of Sitges. Although grains were the dominant crops in the greater part of the region, from the beginning of the eighteenth century, viticulture began to expand from coastal to interior areas (Ciurana 1991: 122).

The expansion of vineyards was closely related to the development of production and trade of distilled liquors (aiguardents). England and Holland, two great consumers of this type of products, had imported them for many centuries from French Atlantic regions, especially from Charant. However, hostile relations with France that brought the outbreak of war in 1672 led them to find in Catalonia a new supplier of distilled liquors. In 1685, a distillery was established in the Catalan town of Reus by an English merchant, called John Shallet, and another in Vilafranca del Penedès in 1692. From that moment, the export of aiguardents from Penedès grew rapidly, also reaching Spanish colonies in Latin America via the port of Cádiz (Valls Junyent 2003a: 76-81).

Distillation of wine had various advantages for the Catalan local peasants. First, distillation permitted to convert voluminous and perishable wine into an other type of product, much more resistant to long travel. In interior parts of Penedès, until the arrival of the railway in the mid-nineteenth century, the lack of fast means of communication had made it hard to transport wine to remote markets. Even in towns situated relatively near the sea, like Vilafranca del Penedès, transportation of wine on the back of packhorses would result in high shipping costs, and also in alteration of the quality of the wine. Distillation signified a double solution: production at a low risk of deterioration and reduction of the bulk transported (Giralt i Raventós 1952: 166).

Secondly, aiguardents did not normally require grapes of quality, so that in a region not highly valued by physical conditions, the production of aiguardents brought a more profitable use of vineyards and more possibilities in the market. Furthermore, since aging was not required for aiguardents, the production process was relatively simple. Once having obtained the must, the remaining work could be carried out just with a distiller that was available at low prices (Simpson 2001: 143).

For these reasons, the production of aiguardents diffused with relative ease among winegrowers of Penedès, and the penetration of foreign capital was practically insignificant, except for some initial cases mentioned before. The liberalization of the trade with Latin America that took effect in the last decades of the eighteenth century came to be an additional incentive for the production and export of $a i$ guardents.

In the nineteenth century, the trade of aiguardents began to decline, due to the independence of Spanish colonies and also changes in the north European market (Valls Junyent 2003a: 81-89). Although the loss of clients left the local producers in an adverse situation for a time, from the decade of 1870 , this was compensated by the export of wine to France, where the great part of vineyards had been damaged 
by the plague of phylloxera.

The wine production in Penedès attained its peak toward the end of the nineteenth century, with vineyards expanded practically all over the region, in many cases displacing conventional crops. However, contrary to the case of Jerez, development was largely limited to quantitative rather than qualitative aspects, since what French traders sought from Spain was not wine of quality, but red wine with intense color and high alcohol content to blend it later with French wine (Mestre i Raventós 1987: 248-257).

An important exception to the situation described above was the creation of a kind of sparkling wine, called cava. Behind the boom provoked by the plague in the neighboring country, Josep Raventós, founder of the most important Spanish company of sparkling wine, Codorníu (1), was experimenting with the traditional champagne method in his bodega situated in Sant Sadurní d'Anoia (Figure 5). The result was a wine of original taste on the basis of Catalan indigenous grape varieties, such as parellada, macabeu and xarel.lo (Sen 1990: 1218; Torres 1987: 58-59). From the 1890s, when Codorníu decieded to specialize in cava, the sale of this company showed a spectacular increase: from 3,276 bottles in 1890 to 117,396 in 1899 (Giralt i Raventós 1993: 70).

The cava successfully launched on the market by Codorníu diffused gradually among wine-growers of Sant Sadurní d'Anoia area, and

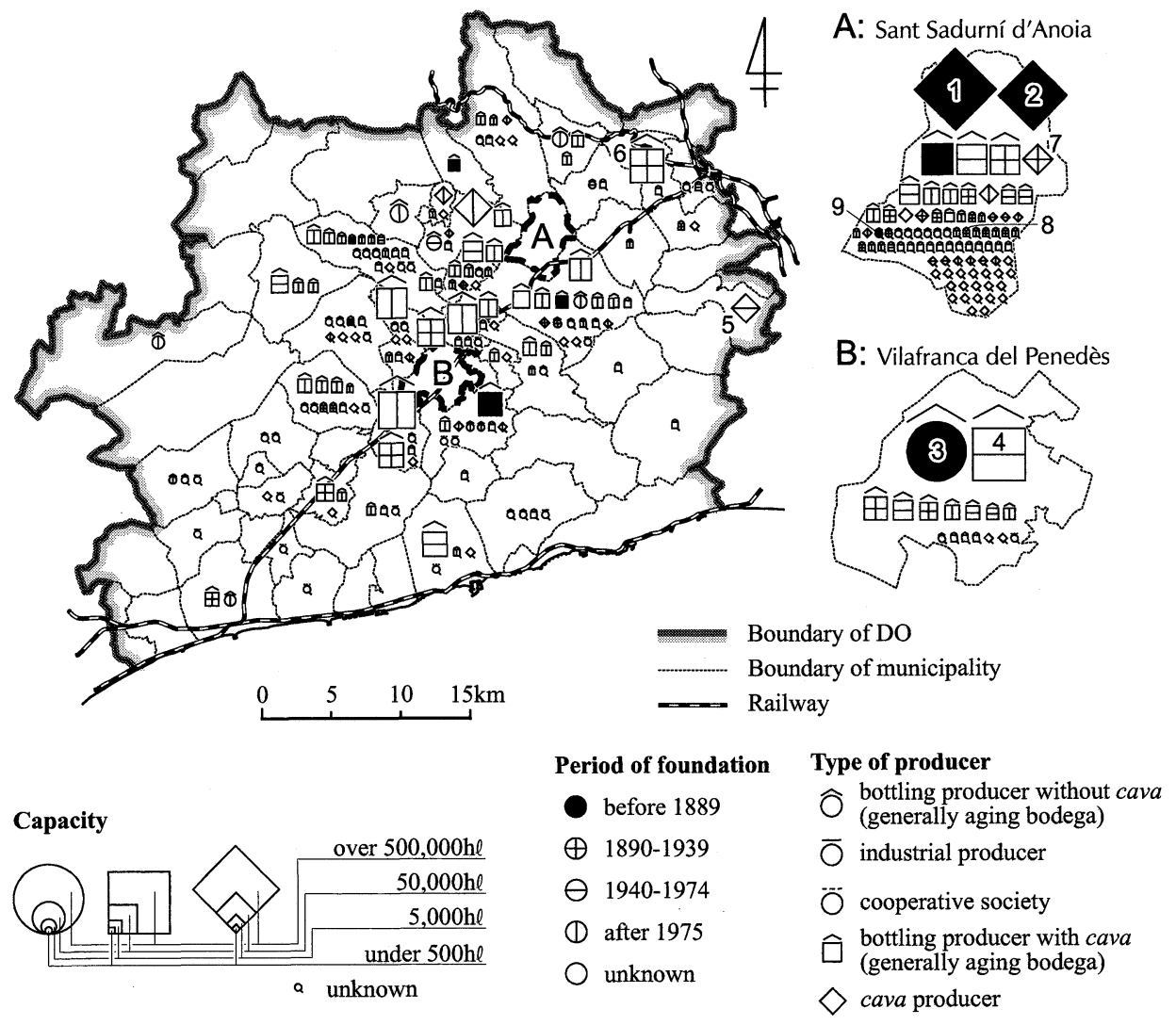

Figure 5. Registered wine producers in the Denomination of Origin of Penedès (2002).

Note: This figure also contains producers which are registered only in the DO Cava in spite of their location inside of the geographical delimitation of the DO Penedès. Such is the case of the producers working only in the elaboration of cava. Wine-growers that combine still wine with cava are controlled by both of the two DOs in question. Cooperative societies that are engaged in aging as a fundamental part of their activities are included in bottling producers with/ without cava.

Source: Ediciones El País (2002) and data from the Regulatory Council of the Denomination of Origin of Penedès and that of Cava. 
since that moment, began to draw the development of commercial wine production to Penedès (Llobet 1959: 467-468). World War I was a period of prosperity for Penedès, since Spain, as a neutral country, could afford to meet the international demand for sparkling wine in place of France, which underwent a sudden decline in wine production and trade because of the war (Valls Junyent 2003b: 157-159).

One of the most significant events for the specialization of the region in cava was the plague of phylloxera that scourged Catalan vineyards from the 1890 s to the 1910 s. Practically all the vines for red wine were damaged, and when the replantation was carried out, most vine-growers opted for vines of white grape varieties taking advantage of the success being experienced by the production of cava (Rexach 2000: 175-176).

What the cava had in common with the other pioneer product of Penedès, aiguardents, was the relatively small capital required to work with it, although a certain degree of technique and experience was indispensable. The cava needs aging process, but it is not realized in casks but in bottles, which saves the initial investment to a considerable extent. This fact facilitated the appearance of many winemaking family companies in Penedès, almost all of them emerging from their ancestral agricultural activities.

Also important was the role played by the unit of agricultural exploitation based on the primogeniture, called masia. Farmland controlled by a masia was quite larger than that of other types of agricultural exploitation found in northern Spain. However, contrary to the latifundists of the South, the proprietors of $m a$ sia dedicated themselves to the management of farm, and many of them, not only as a farmer but as a rural entrepreneur, were willing to undertake new business (Giralt i Raventós 1993: 80). So, it was often proprietors of masia with enterprising culture who, tied up with Catalan merchants, took a leading part in the production of aiguardents and cava.

In the 1960s, Penedès went through another period of renovation, led by some enterprising wine producers, like Miguel Torres or Jean León. These entrepreneurs of new generation directed their attention to the microclimatic diversity in Penedès so as to produce a new type of wine still unknown in Spain. Their project proved successful. Finally they were able to acclimate some foreign grape varieties to the local conditions, such as cabernet sauvignon, merlot or chardonnay, native to north European countries and highly valued in the international market. In this way, they succeeded in differentiating their products from those produced from Spanish indigenous varieties like tempranillo, that is, the typical variety of Rioja (Nadal 2003: 116-117).

Penedès was also a pioneer in the introduction of modern equipment, such as stainless steel fermentation tanks or thermoregulation system, as well as some sophisticated vinification methods, like refrigerated fermentation or aging in new oak casks. All these efforts for renovation permitted Penedès to become one of the leading wine-producing regions in Spain, leaving behind its conventional role as a supplier of bulk wine to foreign markets, apart from the cava. While in the 1960s more than half of the must produced in the region was exported to foreign companies that would transform it into sparkling wine or grape juice, at present the proportion of the wine sold in bottles is over $80 \%$, of which still wine accounts for almost half. ${ }^{9}$

An important change that is taking place recently in Penedès is the emergence of many small and middle-sized aging bodegas. Although there has been a certain penetration of investors from outside the region, most of the newly founded bodegas have evolved from local vine-growers or small wine producers that, until some decades ago, made must solely for larger bodegas. The presence of these new bodegas rejuvenates considerably the whole structure of wine industry in Penedès (Figure 5), and also contributes to raise the average quality of the wine produced in the region, and consequently its market value.

Today, as the cava continues to be the emblematic product of Penedès, the majority of wine-growers are bottling producers, generally aging bodegas, that combine the production of still wine and that of cava, while the rest can be divided basically between cava producers and a 
small number of bottling producers without cava (Figure 5). Significantly the three big companies constitute two different prototypes of wine producers in Penedès: Codorníu and Freixenet (2) as cava producers, and Miguel Torres (3) as an aging bodega without cava. Thus, other producers of the region found in these precedents, in a certain measure, two models to imitate and develop their own way, and most of them have chosen to combine the two.

On the other hand, in spite of the recent expansion of aging bodegas, the great majority of the vineyards belong to cooperative societies and individual vine-growers. In fact, among around one hundred aging bodegas that exist at present in Penedès, just little more than half have their own vineyards, and even these bodegas often cover part of their necessity with purchase from vine-growers. ${ }^{10}$

The cooperative societies, in which nearly half of the vine-growers of the region are associated, can be classified into two groups: cooperatives that age and bottle part of their production and those working only in the elaboration of must (Ribas i Beltrán 2002: 75). COVIDES (4), the most important cooperative in the region, is a representative case of the first group, and it operates practically like a big aging bodega with influence over the whole sector. By contrast, another important cooperative, CEVIPE, is a union of eleven smaller cooperatives engaged only in the production of must.

Additional mention should be made of the so-called "industrial producers." Working as large factories of must, these companies normally do not have their own vineyards, nor bottle the wine they produce. A similar function is carried out also by some individual winegrowers of modest dimensions, although on a much smaller scale. The three big companies of the region are the principal customers of the must produced by these three types of producers. ${ }^{11}$

As described above, from a functional viewpoint, in Penedès there is a relatively clear division between aging bodegas together with cava producers, and individual and associated vinegrowers. In contrast to Rioja, where individual wine-growers (cosecheros) often have a respectable place as producers of bottled young wine, in Penedès the presence of this type of producers is almost insignificant. In this polarized schema, the emergence of many qualified aging bodegas is a novelty of great relevance that modifies the oligarchical structure headed by the three big companies, enriching the middle range of wine producers.

Another distinctive feature of the wine industry in Penedès is the overwhelming importance of local capital, and more concretely, of the local family companies which, departing from their modest origin, have grown on the basis of their own wine-producing activities. In fact, from small bodegas to the biggest three, many companies remain in the hands of the founder family. Although there are cases where the proprietor, because of debt or absence of an heir, was forced to pass over the property to another family, the great majority of wine producers continue working as family companies.

Nowadays, the most successful family bodegas follow an active strategy to expand their activities through acquisition of other smaller companies. Codorníu has recently formed an extensive group integrating many bodegas of the region, such as Cavas Rondel (5) and Masía Bach (6), and Freixenet has affiliated with Castellblanch (7), Canals \& Nubiola (8) or René Barbier (9), among other bodegas. Also notable is the expansion beyond the Spanish frontier of these two companies, along with Miguel Torres, which since some decades ago have their own bodegas in California and Chile.

\section{Rioja}

Exceptional physical conditions for viticulture constitute a great asset for Rioja, recognized today as one of the most prestigious wineproducing regions in Spain. Situated equidistant from the Atlantic Ocean and the Mediterranean Sea, the influences from the two seas are combined with the protecting effects of the surrounding mountains to maintain continuously moderate climatic conditions in the region (Fig. ure 6). The type of soil, predominantly chalky clay, is also considered to be adequate to produce grapes of quality, especially the most characteristic variety of Rioja, tempranillo (Table 1). In spite of the privileged physical conditions, 


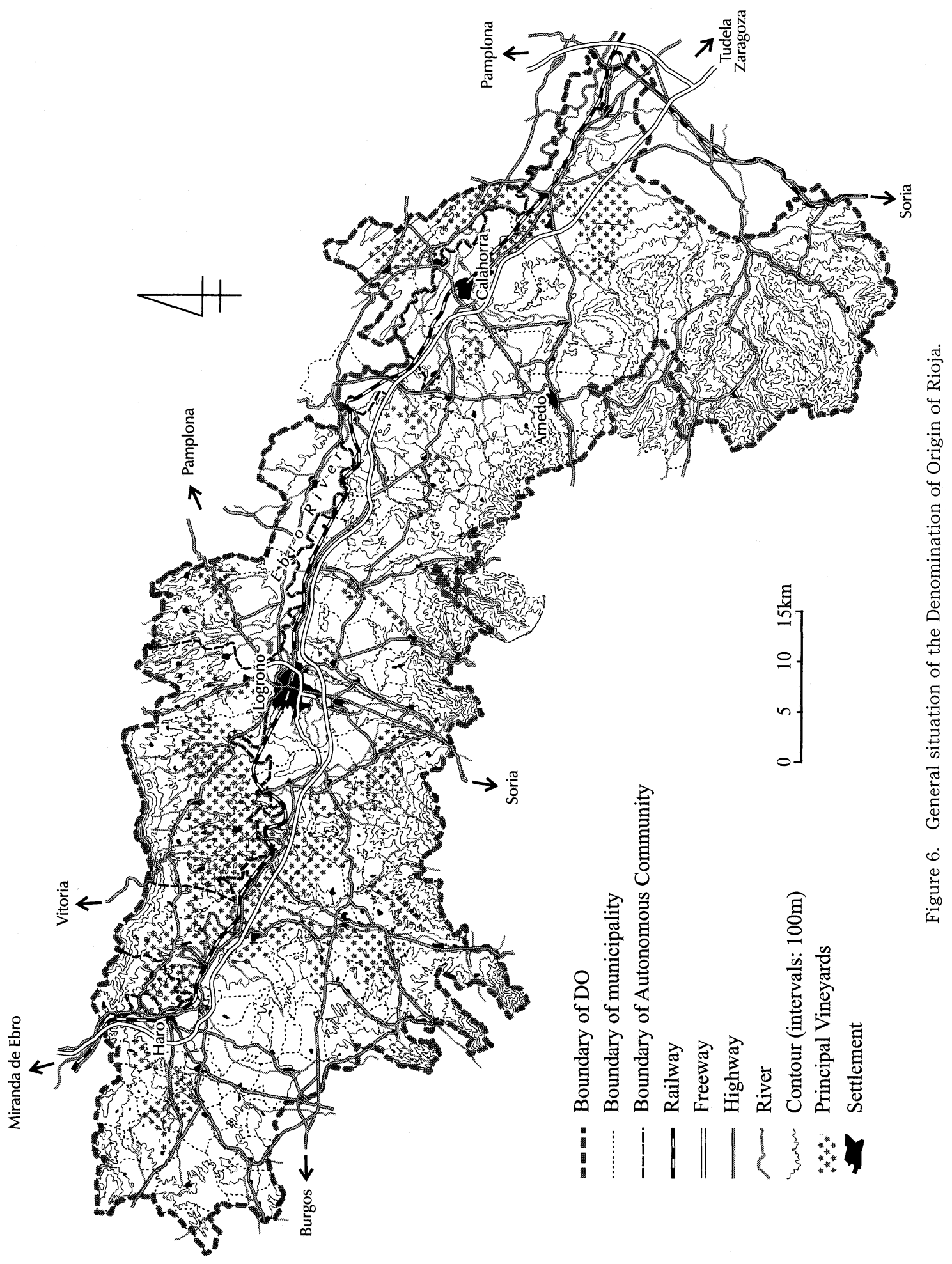




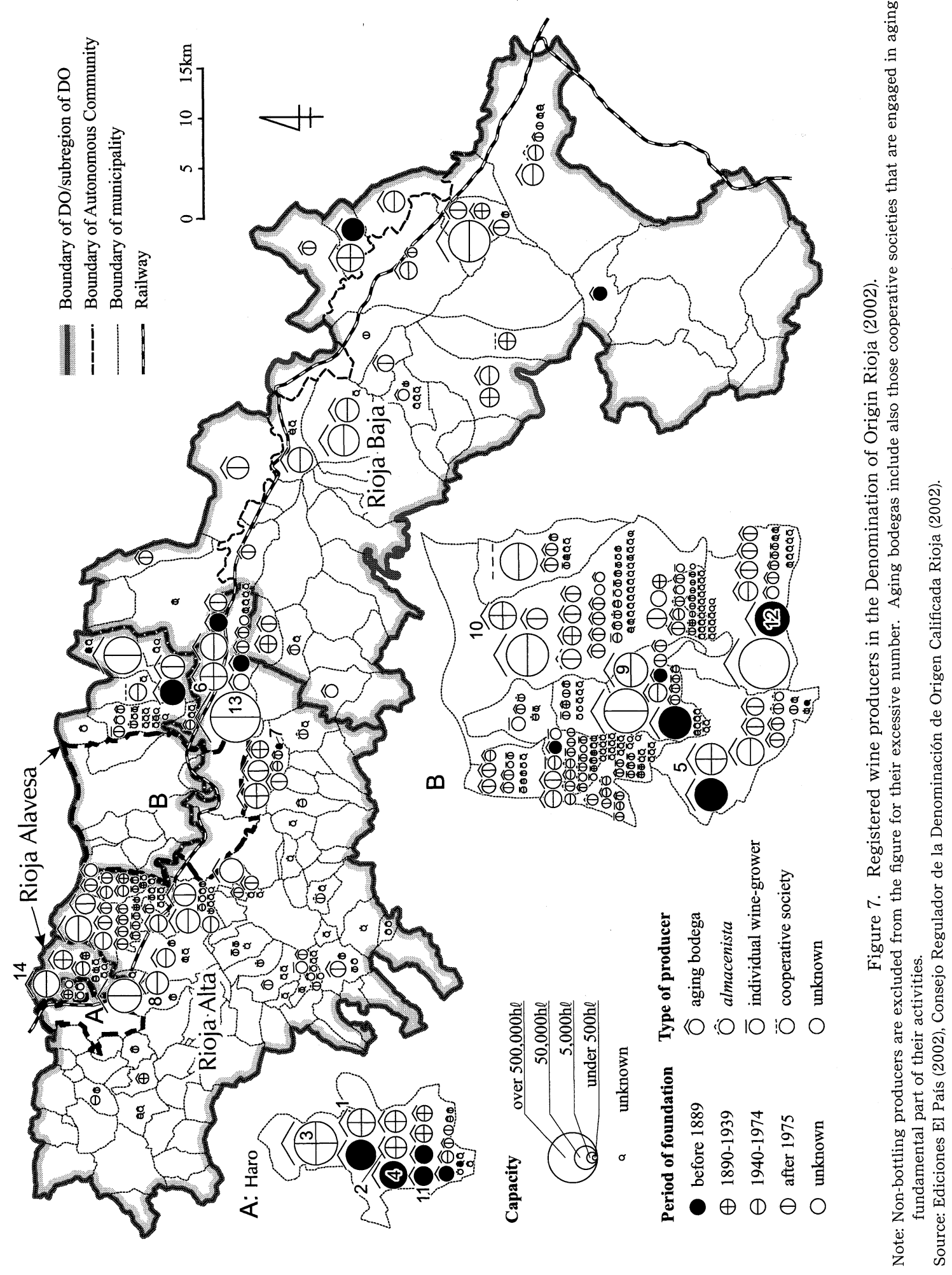


Rioja did not enter the stage of commercialoriented wine production until the late nineteenth century. One of the most important obstacles lay in its geographical location, and more concretely, the relatively long distance that separates the region from the sea. Like other interior regions of Spain, Rioja suffered for a long time from the deficit of good means of transportation. The land transportation had problems of irregularity and insecurity caused by the deteriorated conditions of roads, which in turn increased considerably the economic costs of shipping, especially for voluminous commodities like wine (Gómez Mendoza 1982: 208-209).

Lacking commercial opportunities on larger scales, wine producers of Rioja would trade with nearby areas like the Basque Country, or at most, the coastal region of Cantabria (Huetz de Lemps 1967: 411-421). Although prosperous cities of the Basque Country were an important market for Rioja, its dimension was clearly insufficient to permit a definitive transition to commercial wine industry. Nor could the local market absorb the surplus of the wine produced in the region, due to the low population density.

Another consequence brought by the absence of commercial opportunities was the delay in the improvement of vinification methods. Until the nineteenth century, wine producers of Rioja elaborated only wine of mediocre quality that could not be conserved more than a year. In fact, the traditional vinification in Rioja was completely rudimentary: Grapes were fermented with stems; harvest of different varieties or different maturity were mixed before the fermentation; the must was not stocked nor aged for lack of space and recipients, etc (Gallego Martínez 1986).

However, in the second half of the nineteenth century, two determining events coincided in the wine industry of Rioja to accelerate definitively the process of commercialization: the construction of railway and the plague of phylloxera in France. With the opening of the station of Logroño in 1864, the railway network began progressively connecting principal wineproducing villages of Rioja. The route established between Logroño and the Basque city of Bilbao was linked later with the line between
Madrid and Irún, a small town located on the frontier with France (Huetz de Lemps 1967: 525).

Paradoxically, what gave the railway its real value as supporting infrastructure for the wine industry was the plague of phylloxera that devastated the greater part of the French vineyards in the decade of 1870 . French merchants and wine producers severely hit by the shortage of grapes and wine found Rioja to be an excellent new supplier because of its geographical proximity to France, the improving railway network, and also for its privileged physical conditions (Palacio Sánchez 1991: 63). From the 1870s onwards, these Frenchmen rushed into Rioja establishing bodegas and warehouses near the railway stations so that they could ship immediately to their country the wine bought from local producers (Huetz de Lemps 1993: 118). A large amount of wine was shipped to France by train, and with the growth of the export, vineyards expanded to many villages of the region, mainly to the current subregions of Rioja Alta and Rioja Alavesa (Figure 7).

Although the expansion of market provoked by the plague in the neighboring country also benefitted other wine-producing regions, it was in Rioja where an important innovation took place in the vinification system, contrary to the other regions, including the Penedès of that period, which continued to produce wine of poor quality destined for the French market. Changes emerged from some prominent figures, such as the Marquis of Murrieta or the Marquis of Riscal, who introduced the Bordelais method developed in the French region of the same name. They discovered that this new method, based on aging in oak casks, could be matched with the tempranillo variety to obtain quality wine with unique characteristics (Gómez Urdáñez 2000: 61-64).

However, the introduction of the Bordelais method required a considerable amount of capital to be invested in the storage and aging facilities. So, this innovative system, in spite of its long-term advantages, was out of reach of most local vine-growers. Nor did they want to take the risk of contracting debts. For most of the local producers, it was more attractive to 
obtain immediate return from their vineyards, rather than to leave their wine in expensive casks without knowing what they would get really from it. As a consequence, those who took interest in the new method were practically only aristocratic proprietors, or some bourgeois of the Basque Country where, with the development of the iron industry, demand for quality wine was generated among the urban population (Pascual 2003: 31). They made use of their abundant financial resources to establish so called industrial bodegas equipped with modern installations, and began to produce wine in large quantities based on the Bordelais method.

The 1890 s to the 1910 s was the more intensive period in the creation of new industrial bodegas (Oestreicher 1994: 145). Most entrepreneurs tried to take advantage of the facilities of the railway just constructed, so that the bodegas founded in that period show a remarkable concentration around the principal railway stations (Figure 7). To mention some representative cases, La Rioja Alta (1890) (1), Martínez Lacuesta (1895) (2), Bodegas Federico Paternina (1896) (3) and Bodegas Bilbaínas (1901) (4) were all located in the village of Haro, and another important bodega of the time, Bodegas Riojanas (1890) (5) was erected in Cenicero.

Also some French people who had come to Rioja escaping from the plague of phylloxera discovered the virtues of this region and remained there even after their vineyards recovered from the damage. They associated with local producers to establish new bodegas, of which a typical case was Bodegas FrancoEspañolas (6), founded in Logroño in 1890.

With the development of the newly founded bodegas, the wine production in Rioja came to be polarized between a limited number of industrial bodegas, barely related with viticulture, and innumerous local producers, who were basically small vine and wine-growers. In a region like Rioja, where farming lands were fragmented into small properties, it was difficult for the industrial bodegas to secure a sufficient extension of vineyards to cover all their necessity. So they had to depend on local vine-growers for the supply of raw materials. On the other hand, the local producers without resources to invest in the Bordelais method had no alternative but to provide grapes and must to large bodegas, which in turn would process them into final products. In this way, the polarization between the local producers engaged in the production of grapes and must and aging bodegas (criadores) specializing in aging, bottling and shipping was gradually consolidated (Pascual 2003: 174-176). Although some few almacenistas work as mediators between the two types of operators, contrary to the almacenistas of Jerez, those of Rioja normally do not have aging facilities, and specialize in the storage of must provided by local wine-growers to resell it to aging bodegas. ${ }^{12}$

In spite of the rising importance of the wine industry in Rioja, the local vine-growers did not initially associate in cooperative societies, in contrast to the Catalan peasants, who were precursors of the cooperative movements in Spain. In Rioja, most vine-growers were integrated in the supply network of the industrial bodegas, and those who could offer grapes of fine quality sought for a stable relationship with a specific buyer. It was only in the decades of 1950 and 1960 when, supported by the promotion policy of the Franco regime, many cooperative societies appeared in Rioja (González Larraina 1996: 363). Especially in Rioja Baja, where viticulture had a secondary place to other crops like cereals or vegetables, cooperation gained general acceptance.

The characteristic wine-production in Rioja, based on the Bordelais method and the tempranillo variety was inherited generation after generation. It also gained a reputation in the international market, in particular in the European countries and the USA, and the total export of the region showed a rapid increase, evolving from 4.9 million litters in 1952 to 40.7 million in 1972 (Pascual 2003: 47).

From the beginning of the 1970 s, the consolidation of Rioja as a prestigious wine-producing region again attracted the interest of many investors. Large companies of Jerez, various multinational enterprises and some Basque and local entrepreneurs directed a great deal of capital to Rioja, establishing new bodegas or purchasing existing facilities (González Larraina 1996: 364). 
Some sherry companies were among the most active investors in Rioja. The RUMASA group, which under the direction of Ruiz Mateo had controlled several important bodegas in Jerez, bought Bodegas Federico Paternina and Bodegas Franco-Españolas in 1971. The already mentioned Osborne acquired Bodegas Montecillo (7) in 1973; González Byass bought Bodegas Beronia (8) in 1982; and Pedro Domecq founded a new winery, Bodegas Domecq (9), in 1973.

As for multinational investors, a Canadian multinational distiller, Seagram, bought Bodegas Palacio (10) in 1977, although they finally decided to withdraw. Also Pepsi-Cola controlled for some time Bodegas Rioja Santiago (11). In 1973, Bodegas AGE (12) passed to the hands of Schenly, the biggest distiller in the world at that time (Gómez Urdáñez 2000: 142).

Among the Basque capitalists, the SAVIN group, today called Bodegas y Bebidas, is outstanding for its dimension. This group, after creating Bodegas Campo Viejo (13), was absorbed by Allied Domecq in 2001. The latter, controlling also numerous bodegas inside and outside Rioja, has finally become the biggest group in the wine industry of Spain.

On the other hand, the traditional polarization between industrial bodegas and local producers did not change radically even after the arrival of new investors. In fact, many industrial bodegas founded in the last thirty years have their origin in commercial or financial activities, and are rarely provided with sufficient extension of vineyards to cover their necessity. Rather, the entrepreneurs preferred to specialize in aging, bottling and commercializing of wine. In this strategy, what matters to these entrepreneurs is the establishment of stable relations with local producers to obtain grapes and must of optimum quality that permit them to elaborate a distinguishable wine and then appeal to the market.

In the last decades, the polarized structure just detailed is changing partially, due to some individual wine-growers (cosecheros) that have begun to produce young wine to sell it bottled on the market. Originally the fundamental activity of the local wine-growers consisted in the elaboration of must from their own harvest, and they normally sold it in bulk to industrial bodegas. However, the young wine they would produce, known as vino de cosechero (wine of cosechero), was also appreciated among local and regional consumers for its special characteristics: more acid and fruity than the conventional wine because of the practice of carbonic maceration, that is, fermentation of entire clusters without separating grapes from the stem. Aware of the appeal attributed to the young wine of Rioja, some individual wine-growers decided to extend their business by presenting their products in the market. ${ }^{13}$

Furthermore, from the middle of the 1980s, some individual wine-growers with sufficient resources to invest in the improvement of equipment have been incorporated gradually into the market of quality wine as new aging bodegas. This tendency is remarkable particularly in Rioja Alavesa, where there is a relative predominance of individual wine-growers and small-sized aging bodegas, against the important presence of industrial bodegas in the other two subregions (Figure 7). Situated on the easy slope formed by the Cantabrian mountains, Rioja Alavesa is considered to meet the best conditions to produce quality wine from the tempranillo variety: transitional climate influenced by the two seas, moderate temperature and precipitation, and chalky-clayey soil with sufficient drainage. Those who know how to make the best use of these physical conditions are the wine producers of modest dimensions, who today distinguish themselves not only as good suppliers for industrial bodegas, but as experienced producers with control over the whole process, from the vineyards to bottling.

The favorable situation of Rioja Alavesa is also reinforced by the current regulations of the DO Rioja that recognize the three subregions defined basically by the physical conditions as well as the administrative demarcations (Figure 7). The producers are not obliged to indicate the subregion on the label, since many aging bodegas, particularly large industrial bodegas, operate beyond the limit of the subregion seeking for an adequate combination of raw materials for their own brand. However, if a producer wants to specify the subregion on their products, then the grapes and must should come 
from the same subregion. Naturally those who intend to differentiate themselves from others are the producers of Rioja Alavesa, who enjoy today a high reputation in the domestic and international market, releasing new products under the name of "wine of Rioja Alavesa."

Innovative changes are also taking place among cooperative societies. After a long period of specialization in the elaboration of must, many cooperatives have already begun to sell bottled young wine with their own label, and in some cases, even aged wine of quality (Huetz de Lemps 1993: 291-293). Unión Cosecheros de Labastida (14) is a typical example of the cooperatives that, with the joined force of the vinegrowers, are working today as big aging bodegas.

\section{Discussion}

In the three Spanish wine-producing regions studied in this article, there is commonly a prototype of entrepreneurs that took the initiative in the innovation and commercialization of wine production. The leading actors, however, show important differences among the three regions considered, not only by their geographical and economic origins, but also by the way they exploited their surrounding conditions, such as natural environment, accessibility to the market or availability of means of communication.

In Jerez and Penedès, open respectively to the Atlantic Ocean and the Mediterranean Sea, the entrepreneurs benefitted from this privileged situation from the early stages to commercialize their products in foreign markets. A decisive factor for the specialization of Jerez in fortified wine was the growing demand for it among the English people, who in the sixteenth century found in that Spanish Atlantic region the potential to be an efficient supplier. So it was not the local wine producers but rather the foreign merchants settled in the region who took the helm of wine production and sales. Sensitive to the changes in the demanding English market, they developed their unique solera system to create a new type of wine with stable quality. These well-funded foreign merchants, who could introduce this expensive system, soon gained great influence over the whole sherry industry as powerful shippers.

In contrast to Jerez, most of the leading wine producers in Penedès have their origin in local vine-growers, dedicated for many generations to producing wine for local consumption. From the eighteenth century, however, they tied up with Catalan merchants to launch themselves successfully on foreign markets, for which the principal strategy was specialization in some emblematic products, first aiguardents and later cava. In the twentieth century, after the reputation gained by the cava in the international market, initially compensating for the French champagne severely affected by World War I, another process of innovation emerged from some enterprising local wine-growers. The sophisticated vinification methods they introduced gave still more impetus to the wine industry in Penedès, permitting it to penetrate the market of qualified still wine.

Meanwhile, in Rioja, the possibility of export was extremely limited until the construction of the railway reduced considerably the difficulties of land transportation. Nor was there a large consumer market around the region. It was in the late nineteenth century when, with the opening of railway and the devastation of French vineyards by the plague of phylloxera, the great potential of the vineyards of Rioja were "discovered" by many entrepreneurs. The investors attracted by those vineyards, such as Spanish nobles, Basque capitalists or French wine producers, played the leading role in the modernization of the wine industry in Rioja. The main instrument for renovation was the introduction of the Bordelais method, applied to the endogenous variety of tempranillo. Fruit of the combination of this new aging system and the excellent physical conditions was quality red wine with distinguishing characteristics, which has raised Rioja to an outstanding position not merely in the national market, but also abroad.

The relationship between the entrepreneurs described above and the other operators involved in the wine production also differs considerably among the three regions, depending to a great extent on the type of leading actors existing in each region. 
In Jerez, shippers of large or medium dimensions, mostly owned by multinational companies, have great influence as historical promoters of sherry, reinforced by the possession of large and grand solera. This position allows them to control the other operators under conditions favorable to their own interests. In such a situation, the local vine-growers as well as the elaboration bodegas rarely have alternatives to their conventional role as suppliers for shippers and almacenistas, although some cooperatives intend to sell their products with their own brand. Recently the shippers have increased their influence further, affiliating with other companies. They are also looking for more efficient control over the production process through purchase of the best vineyards endowed with albariza soil.

Also in Penedès, the wine industry had a polarized structure until some decades ago. The three big companies were situated at the top, whereas the rest, except for some middlesized cava producers, consisted of a large number of vine-growers and small wine-growers that worked as suppliers for the big three. From the 1980s onward, however, many winegrowers ceased to be mere suppliers of bulk wine to become new aging bodegas, some of which are appreciated today for the quality of their products. This shift of small producers to the intermediate position has contributed considerably to moderating the existing polarization.

In Rioja, there was traditionally a clear separation between the aging bodegas founded by well-funded investors and the local vinegrowers along with individual wine-growers. The local producers who could not afford to introduce the Bordelais method were obliged to sell grapes or must to large aging bodegas, which in turn would send it to the market, generally after several years of aging. Nevertheless, in the last decades, not a few individual wine-growers decided to sell their bottled young wine, sometimes aging part of the production. Although even today the majority of individual wine-growers continue to be nonbottling producers, some bodegas are wellknown for the quality of their wine, based on the careful control they realize through the en- tire production process, from the vineyards to the bottling.

Finally, it is worth pointing out some spacial implications, derived partially from the relationship between the leading entrepreneurs and the other operators.

In Jerez, this relationship resulted in a clear center-periphery structure. The center is occupied by the shippers, and from the viewpoint of natural environment, it is delimited by the existence of albariza soil. Furthermore, this structure is strengthened even more by the current legislation that recognizes the exclusive use of the DO Jerez for the mentioned center.

Rioja also has subregions recognized by the DO regulation. However, those areas are not defined necessarily by the logic of center and periphery historically engendered, but rather determined by the differences in physical conditions as well as the administrative demarcations. At present, those who claim to question this situation are the wine producers of Rioja Alavesa, mainly small and middle-sized aging bodegas, while the big companies, which often develop their activities over several subregions, have long since had their brand consolidated. What the bodegas of Rioja Alavesa are looking for is differentiation from other wine producers, gaining the maximum economic and symbolic value for their excellent vineyards.

Contrary to the other two regions, Penedès has not yet established an official definition of subregions. However, individual producers are becoming conscious of the microclimatic and edaphic differences among the subregions, and some bodegas take advantage of this diversity to cultivate a wide range of vines, bringing about an equally important diversity in the final products.

\section{Acknowledgments}

The authors are grateful to Mr. César Saldaña, Mr. Josep Ribas i Beltrán and Mrs. Gloria Cunchillos Abad at the Regulatory Councils of DO Jerez, DO Penedès and DO Rioja, respectively, for providing us with valuable information and materials that helped us to make a solid basis to proceed with our survey. We also express our gratitude to many wine producers who generously shared with us all they have done in their vineyards and bodegas to arrive to the present 
with a rich patrimony that we appreciate deeply.

(Received 31 October 2003)

(Accepted 20 December 2003)

\section{Notes}

1. The official name of the DO Jerez and the DO Rioja are "Denominaciones de Origen JerezXérès-Sherry, Manzanilla-Sanlúcar de Barrameda y Vinagre de Jerez" and "Denominación de Origen Calificada Rioja," respectively. In this article, the abbreviated forms are always employed.

2. For details on the DO regulations, see Saito (2004).

3. The producers surveyed for this study are the followings: Jerez: Bodegas Barbadillo, Cooperativa Católico-Agrícola, González Byass, José Mellado Martín, María Pilar García de Velazco Pérez (La Cigarrera), Pedro Domecq; Penedès: Cavas Parés Baltà, Codorníu, Huguet de Can Feixes, Jané Ventura, Miguel Torres; Rioja: Bodegas Gómez de Segura Ibáñez, Bodegas Luis Cañas, Bodegas Hermanos Peciña, Bodegas Muga, Bodegas Ontañón, Bodegas Palacio, Bodegas Pérez Maestresala, Sociedad Cooperativa Bodegas San Sixto, Bodegas Juan Alcorta, Puelles Fernández, Unión de Cosecheros de Labastida, Viñedos y Bodegas de la Marquesa.

4. The number inserted after the name of a producer corresponds to the number assigned to the same producer in the figures 3,5 and 7 .

5. Although the shippers have similar functions to those of the aging bodegas that operate in the other two regions, they are generally called shippers for their origin as exporters of sherry.

6. Based on the interview to the Regulatory Council of the DO Jerez.

7. Ibid.

8. In this article, the word "must" does not refer to the juice obtained from pressed grapes, but the base wine resulting from the fermentation process.

9. Based on the interview to the Regulatory Council of the DO Penedès.

10. Ibid.

11. Ibid.

12. Based on the interview to the Regulatory Council of the DO Rioja.

13. Ibid.

14. Ibid.

\section{References}

Bachelard, I., Peris, A., and Pla Payà, S. 2002. Larousse de los vinos: Los secretos del vino, países y regiones vinicolas. Barcelona: Larousse.

Ciurana, J. 1991. Els vins de Catalunya. Barcelona: Departament d'Agricultura, Ramaderia i Pesca.
Generalitat de Catalunya.

Consejo Regulador de la Denominación de Origen Calificada Rioja. 2002. Directorio de bodegas embotelladoras de la Denominación de Origen Calificada Rioja. Logroño: Consejo Regulador de la Denominación de Origen Calificada Rioja.

Consejo Regulador de la Denominación de Origen de Jerez. 2002. Memoria de actividades 2002. Jerez de la Frontera: Consejo Regulador de la Denominación de Origen de Jerez.

Ediciones El País. 2002. Anuario de los vinos 2002. Madrid: Ediciones El País.

Gallego Martínez, D. 1986. La producción agraria de Álava, Navarra y La Rioja desde mediados del siglo XIX a 1935. Doctoral thesis. Madrid: Universidad Complutense de Madrid.

Giralt i Raventós, E. 1952. La viticultura y el comercio catalán del siglo XVIII. Estudios de Historia Moderna, II: 159-176.

Giralt i Raventós, E. 1993. L'elaboració de vins espumosos catalans abans de 1900 . In Vinyes $i$ vins: Mil anys d'història, ed. E. Giralt i Raventós, 37-81. Barcelona: Universitat de Barcelona.

Gómez Mendoza, A. 1982. Ferrocarriles y cambio económico en España 1855-1913. Madrid: Alianza.

Gómez Urdáñez, J. L. 2000. El Rioja histórico: La Denominación de Origen y su Consejo Regulador. Logroño: Consejo Regulador de la Denominación de Origen Calificada Rioja.

González Larraina, M. 1996. La revolución enológica riojana de finales del siglo XX. In La Rioja, el vino y el camino de Santiago: Actas del I Congreso Internacional de la Historia y Cultura de la Vid y el Vino (Labastida, Rioja Alavesa, 28 y 29 de septiembre de 1994), ed. J. Santos, 363-369. Vitoria: Fundación Sancho el Sabio.

Grupo Gourmets. 2002. Guía de vinos Gourmets 2002. $17^{\text {th }}$ ed. Madrid: Paladar.

Guerrero Cano, M. M. 1998. Cádiz y la exportación de vinos a América en la época colonial. In El comercio de vinos y aguardientes andaluces con América (siglos XVI-XX), ed. A. Ramos Santana and J. Maldonado Rosso, 49-59. Cádiz: Universidad de Cádiz.

Huetz de Lemps, A. 1967. Vignobles et vins du nordouest de l'Espagne. Bordeaux: Féret \& Fils.

Huetz de Lemps, A. 1993. Vignobles et vins d'Espagne. Bordeaux: Presses Universitaires de Bordeaux.

Jeffs, J. 2000. Vinos de España. Barcelona: Tusquets.

Llobet, S. 1959. La industria del vino espumoso español. Estudios Geográficos, 77: 459-481.

Maldonado Rosso, J. 1999. La formación del capitalismo en el marco del Jerez: De la vitivinicultura tradicional a la agroindustria vinatera moderna (siglos XVIII y XIX). Madrid: Huerga \& Fierro.

Mestre i Raventós, P. 1987. Passat, present i futur de la vinya o el vi al Penedès. Miscel-lània Penedesenca, 1: 239-268.

Ministerio de Agricultura, Pesca y Alimentación. 
2002. Datos de denominaciones de vinos: Campaña 2001/2002. Madrid: Dirección General de Alimentación. Subsecretaría de Agricultura y Alimentación. Ministerio de Agricultura, Pesca y Alimentación.

Montañés, E. 2001. Los exportadores del Jerez, 18351886. In Viñas, bodegas y mercados: El cambio técnico en la vitivinicultura española, 1850-1936, ed. J. Carmona, J. Colomé, J. Pan-Montojo and J. Simpson, 187-208. Zaragoza: Prensas Universitarias de Zaragoza.

Nadal, M. 2003. De l'autarquia a l'expansió del sector vitivinícola (1940-2000). In De l'aiguardent al cava: El procés d'especialització vitivinícola a les comarques del Penedès-Garraf, ed. J. Colomé Ferrer, 113-139. Vilafranca del Penedès: Ramon Nadal.

Oestreicher, A. 1994. Algunos aspectos de la historia del sector vitivinícola riojano, 1865-1915. Berceo, 127: $137-152$.

Palacio Sánchez, J. M. 1991. Historia del vino de Rioja. Logroño: La Prensa del Rioja.

Pascual, J. 2003. El vino de Rioja: Calidad, originalidad y prestigio histórico. Logroño: La Prensa del Rioja.

Ramos Santana, A. 1997. Vinos y aguardientes: Señas de identidad de la provincia de Cádiz. In Vinos, vinagres, aguardientes y licores de la provincia de Cádiz, ed. A. Ramos Santana and J. Maldonado Rosso, 79-94. Cádiz: Fundación Provincial de Cultura de la Diputación de Cádiz.

Rexach, A. 2000. Vins $i$ caves de Catalunya. Barcelona: L'Isard.

Ribas i Beltrán, J. 2002. Penedès, Denominació d'Origen. Barcelona: Cedecorporativo.

Saito Y. 2004. Regional differences in the development of wine industry in Spain. Journal of Geography 113 (in press). (JE)
Sen, M. 1990. El país del cava. Barcelona: Nou Art Thor.

Simpson, J. 1985. La producción de vinos en Jerez de la Frontera, 1850-1900. In La nueva historia económica en España: Reflexiones sobre el caso español, ed. P. Martín Aceña and L. Prados de la Escosura, 166-191. Barcelona: Ariel.

Simpson, J. 1997. La agricultura española (17651965): La larga siesta. Madrid: Alianza.

Simpson, J. 2001. Cooperativas, bodegas y mayoristas: La industrialización de la vinicultura. Introducción. In Viñas, bodegas y mercados: El cambio técnico en la vitivinicultura española, 1850-1936, ed. J. Carmona, J. Colomé, J. Pan-Montojo and J. Simpson, 141-151. Zaragoza: Prensas Universitarias de Zaragoza.

Torres, M. A. 1987. Els vins del Penedès. Barcelona: Nou Art Thor.

Unwin, T. 1996. Wine and the vine: An historical geography of viticulture and the wine trade. London: Routledge.

Valls Junyent, F. 2003a. L'aiguardent, el vi i els mercats de la viticultura penedesenca durant el segle XVIII i la primera meitat del XIX. In De l'aiguardent al cava: El procés d'especialització vitivinícola a les comarques del Penedès-Garraf, ed. J. Colomé Ferrer, 75-94. Vilafranca del Penedès: Ramon Nadal.

Valls Junyent, F. 2003b. La indústria del cava. De la substitució d'importacions a la conquesta del mercat internacional. In De l'aiguardent al cava: El procés d'especialització vitivinícola a les comarques del Penedès-Garraf, ed. J. Colomé Ferrer, 143182. Vilafranca del Penedès: Ramon Nadal.

(JE): written in Japanese with English abstract 